\title{
The Implementation of Think Pair Share (TPS) Learning Model using Realistic Mathematics Approach in Problems Solving
}

\author{
Ita Milandari Khotimah, Marhan Taufik, Hendarto Cahyono \\ Study Program of Mathematics Education \\ Faculty of Teacher Training and Education, \\ University of Muhammadiyah Malang \\ lufitaelfiani65@gmail.com
}

\begin{abstract}
This research aimed at describing the implementation of TPS learning model using Realistic Mathematics Approach in solving problems. The type of research was qualitative descriptive. The subjects of this research were the students of class 8-I that consisted of 20 students. The data collection methods that used in this research were: 1) observation, 2) test, 3) interview, and 4) documentation. The research results indicated that the learning used the TPS model using the Realistic Mathematics Approach in the geometry material of prism and pyramid during four-time meetings overall could be conducted based on what had been planned. The learning stages are adjusted to the students' learning activities in order to improve the students' thinking abilities and skills to solve the problems. The students' mathematical problem-solving ability was high categorized after the implementation of this learning model. It was proven by the test results which indicated that the students were able to master the three important stage namely understanding the problems, planning the completion, and implementing the plans. The understanding stage was by writing down the information from the problems and the information that had been asked from the question very well. In the planning stage, the students also could write down the information into the mathematical model and plan the completion strategy even though it was not complete enough. Therefore, in the model of implementing the plan, the students were able to implement the completion based on the plans and get the results.
\end{abstract}

Keywords: TPS, PMR, Problem-Solving.

\section{INTRODUCTION}

Mathematics is one of the fields of study that occupies an important role in education and commonly called as the queen or mother of science (Turmudi, 2001). In education, mathematics learning is used as a foundation and aims to train the students' mindsets, imagination, and creativity of thinking. The learning mathematics requires an interactive learning model and approach so that it supports the progress of the learning purposes. Realistic Mathematics Education is an approach of mathematics learning that comes from Dutch (Wahyuningtyas, 2014). In Indonesia, the $R M E$ approach is better known as the Indonesian Realistic Mathematics Education (PMRI). This realistic mathematics education approach is a type of mathematical approach that adapted from the $R M E$. According to Fauzan (2003) in Atmini's paper, the $P M R$ approach is characterized by several things namely: a) mathematics is seen as human daily life activities so that the solving of contextual problems is essential in learning; $b$ ) learning mathematics means working on mathematics; c) the students are given the opportunity 
to find out mathematical concepts under the guidance of the teacher; and d) the learning process takes place interactively where the students become the focus of all activities in the classroom.

The PMR approach selects the contextual problems to train the students' problem-solving ability. The problem-solving ability becomes one of the abilities that have to be possessed in the mathematics learning. The mathematical problem-solving is an abstract and complex process, in which it involves the thinking and imagination. NCTM clarifies that the main purpose of mathematics learning is problem-solving (Atik, 2013). In addition, the NCTM also reveals that the purpose of problem-solving teaching in general is to (1) build new mathematical knowledge, (2) solve problems that arise in mathematics and in other contexts, (3) apply and adapt various strategies that are appropriate for solving the problems, and (4) monitor and reflect on the process of solving the mathematical problems (Husna et. al, 2013).

There are several stages used in the problem-solving such as those that are proposed by G. Polya in his book "How to Solve It" (Djamilah, 2009). The four steps to solving the mathematical problems according to G.Polya were: (1) Understanding the problem (understanding the problem, identifying what is known by identifying the facts and what is already known in the problem), (2) Devising plan (making a plan, drawing the technical framework for completion using the facts obtained from the questions), (3) Carrying out the plan (solving the problems, using the chosen completion techniques according to the planned plan/framework), (4) Looking back (looking back, checking the truth of completion whether the answer is in accordance with the asked question or not). If the stages of G. Polya is explained in the form of an image, it will be as follows:

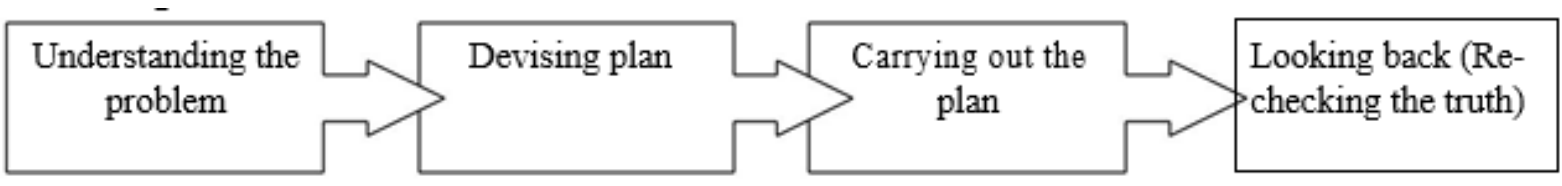

Figure 1. The Problem-Solving Process

The Achievement of mathematical problem-solving ability requires a good mathematical communication using the balanced interactions between the students and other students, or the students and the teacher. Based on these problems, the teacher needs an innovation in mathematics learning that is able to improve the problem-solving ability and make the students play an active role in the learning. When reviewing the expected learning method, one of the alternative methods that can be fulfilled is by using a cooperative learning model. This cooperative learning model is a learning activity that centered on the students to actively interact in building a knowledge. One of the learning models is Think Pair Share (TPS) (Miftahul, 2013). The Think Pair Share learning model is a cooperative learning model that requires the students to pair together for discussion. This learning begins with the teacher giving a problem then the students "think". Then, the students look for a pair "pairing" to discuss the problem, then the results of the discussion with their partner are discussed again with the partner of the entire class "sharing" (Yuni, 2014). This TPS model provides a good result in several previous studies especially in the context of the learning understanding. Based on the results of research conducted by Wahyuningati (2015), one of the conclusions states that the raising between initial understanding and the understanding after using the learning model can increase the learning completeness from $33.33 \%$ to $81.82 \%$, in which it is $48.49 \%$. In addition, a research related to the implementation of the TPS learning model is conducted by Lailatul (2013), which concludes that using the TPS learning model can improve the students' learning activities by mastering 
the material, asking questions and discussing, practicing the creative thinking, and making the students to be able to work on the problem especially the understanding problems (problemsolving).

The TPS model is also suitable for the learning activities in problem-solving and combining them with appropriate and effective approaches. One of suitable approaches is the Realistic Mathematics Education Approach (PMR). The PMR approach is a learning approach that combines the views of mathematics, how the students learn mathematics, and how to teach mathematics. Based on the results of research conducted by Witri (2014) about the problemsolving ability using realistic mathematics learning, the results showed that the mastery of mathematical problem-solving ability could be seen from the pre-test results, of which results showed that the experimental class was $8.83 \%$ while the control class was $10.15 \%$, both are in the poor category. The results experienced a rapid increase after the post-test, in which it showed that the results of the experimental class were $62.27 \%$ while the control class became $45 \%$. So, it can be concluded that the improvement of problem-solving ability using the realistic mathematics learning is better than the direct learning.

The results of the Krismiati (2013) research on the implementation of PMR in groups showed that the learning that used problem-solving in groups could improve the students' mathematical problem-solving ability, especially on the aspects of conceptual understanding, processes, strategies, and connections in the problem-solving. Based on the description above, the purpose of this research is to describe the implementation of Think Pair Share (TPS) learning model using the Realistic Mathematics Education Approach in the problem-solving.

\section{RESEARCH METHOD}

The type of research was descriptive qualitative, in which it produced an overview or illustration of the implementation of Think Pair Share learning model using the realistic mathematics education approach and to find out the students' problem-solving ability. The subjects of this research were the students of $8^{-}$I class that consisted of twenty students. This research used four methods of data collection, namely 1) observation, 2) test, 3) interview, and 4) documentation. The observations were used to find out the implementation of the Think Pair Share learning model using the realistic mathematics education approach; the test was used to determine the students' problem-solving ability; the interview was used to strengthen the students' arguments regarding to the test completed and the documentation was used to capture all of the activities carried out during the implementation process of the Think Pair Share (TPS) learning model using the Realistic Mathematics Education approach. The data were analyzed descriptively: 1) test: the researcher would correct the work results of students by using the scoring rubric in the level of problem-solving ability in writing by determining the students' level, describing each indicator, and concluding the results, and 2) observation: the results of this observation would be explained qualitatively and it was reinforced by the results of documentation in the form of photos when the learning activities took place.

\section{RESULT AND DISCUSSION}

The implementation of TPS model using the PMR approach on the geometry material of prism and pyramid for four meetings overall could be carried out in accordance with the planned learning stages. The teachers' activities and the students' activities during the learning were conducted properly based on the learning stages of the lesson plan $(R P P)$. The stages of that learning model generally included of: 1) the teacher provided the contextual problems by 
adjusting the material, 2) the teacher gave the time to the students for thinking and the students solved the problems individually, 3) the teacher formed pair of students, 4) each pair did a discussion so that they have an answer for the problem, 5) made presentations and the representative of each pair explained (sharing) the results of their group work, 6) after the presentation was finished, the teacher and the students did a class discussion so that they got the conclusion, and 7) the teacher did the reflection and evaluation.

The students' problem-solving ability was seen from the group discussions at the second meeting, the third meeting, and the test that conducted at the last meeting. Based on the results of the students' problem-solving ability which could be seen from the results of the discussion up to the test, it appeared that the level of students' ability was very diverse with an increasing and decreasing in the ability level at each meeting. However, most of the students had reached the levels of 3 and 4 or at the medium level until the high level. The following was an explanation of the level of mathematical problem-solving ability of the student that taken from

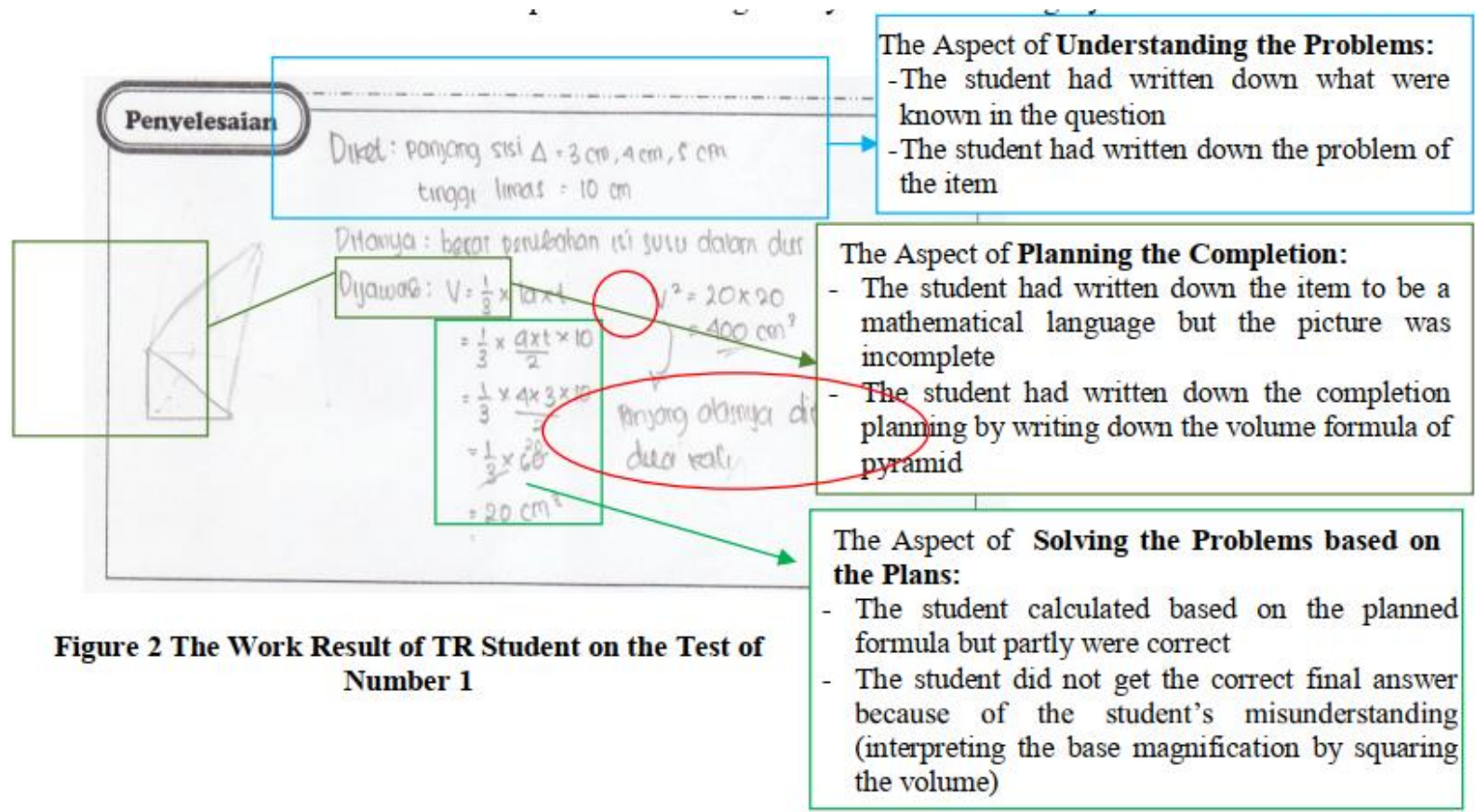

the results of student's work when following the test on the number 1:

a. The student with mathematical problem-solving ability in the low category

When it was viewed at a glance of the results of this student work, it had fulfilled all the stages in problem-solving ability. However, based on the work results of the student, the student still had some shortcomings and errors in the process so that only a few indicators were fulfilled. The aspect of understanding the problem with indicator of writing the known data in the problem and writing down the problems asked in the question were fulfilled with the evidence that the student wrote down what was known and asked correctly and properly. In the aspect of planning the completion, on the indicator of writing the problem into the mathematical language (including drawing) was correct but for the resulting image was still unclear and planning the formula/strategy was only partially correct. In the aspects of solving the problems based on the plan with the indicator of solving the problem in accordance to what had been planned had been run but the student still did not understand what had been written on the known and asked points. This was proven by the students who only calculated the volume of milk boxes before they were enlarged, then the student interpreted the amount of change with the use of the wrong formula. Thus, the indicator got the results of the right answers that in accordance with the taken stages. The student did not meet at all because the answers produced were not appropriate and in accordance with the purpose of the problem. The last aspect, re-checking with the 
indicator of making sure that the answers to the question did not meet because the student did not check it. Therefore, the student's ability level in the question number 1 was located at the level of 2 with a level of problem-solving ability that was classified as low.

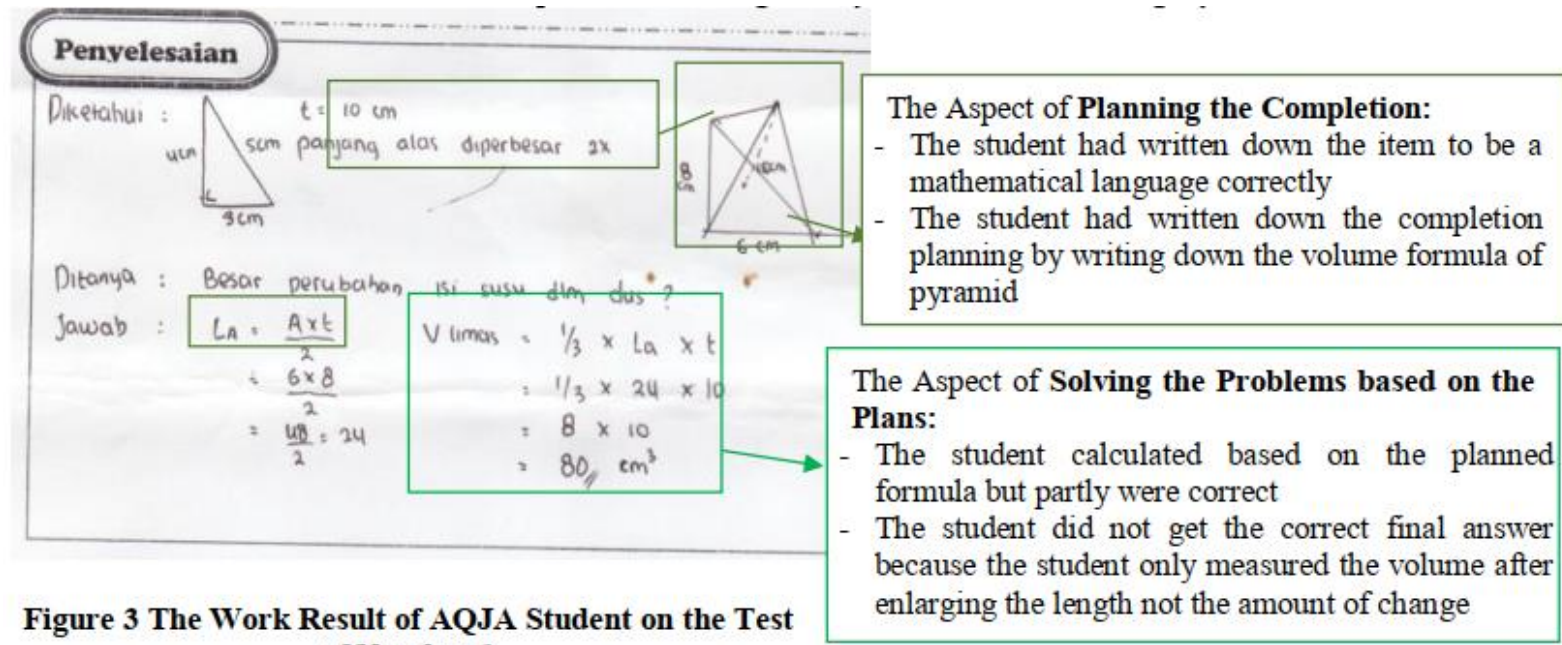
of Number 1

b. The student with mathematical problem-solving ability in the medium category

Based on the results of the work of AQJA students, it showed that the student had fulfilled the completion stages with 4 aspects of problem-solving. However, if it was corrected more thoroughly, there were some indicators that had not been fulfilled. The aspect of understanding the problem with the two indicators and the aspect of planning the completion with the two indicators had also been fulfilled. It was proven by the data that written by the student according to what was known and asked in the question. The student was also able to write it into the mathematical form and draw correctly and write down some of the right formulas to be used in the problem-solving. In the aspect of solving problems in accordance with the plan, on the indicator of solving the problem in accordance with the planned, it had been carried out properly and correctly to the process of the calculation results. From the results of planning formulas which were only partially written, there was a slight misunderstanding of student in understanding the problems asked in the question. The student could not determine the right final result and only part of the process could be calculated correctly. The last aspect, re-checking with the indicator of making sure of the answer to the question was not met because the student did not check it. Thus, the student ability level in question number 1 was classified as level of 3 with a medium of problem-solving ability level.

c. The student with mathematical problem-solving ability in the high category

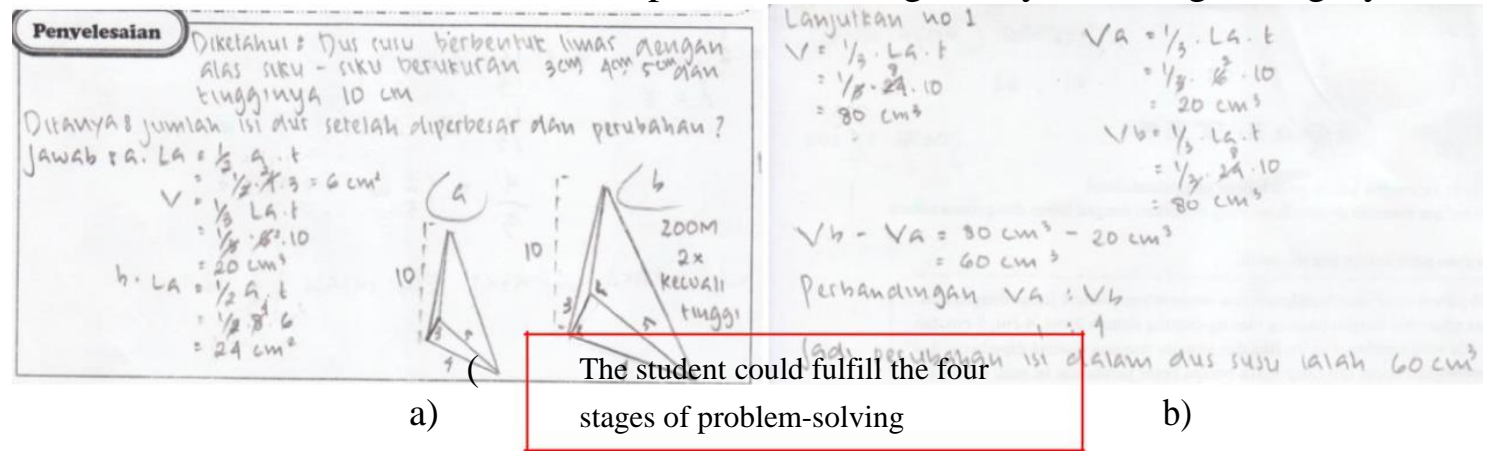

Figure 4 (a) and (b) were The Work Result of ARB Student on the Test of Number 1 
Based on the results of the work of ARB student, it was seen about the accuracy of the work process of student that was in accordance with the stages to solving the problem. The aspect of understanding the problem with the two indicators had been fulfilled as evidenced by the complete and precisely of the student in writing the known and asked points based on the question. The planning of the completion aspect was fulfilled for both indicators, namely writing the mathematical sentence and drawing it correctly and the student wrote down the formula correctly and completely according to the problem that would be solved. The aspect of solving the problems in accordance with the plan, on the indicator of solving the problem in accordance to what had been planned had been carried out properly and correctly so that it obtained the desired results of the question. The last aspect was to check again with the indicator of making sure the answer and the question that was fulfilled because the student had tried to re-check even the student had been able to write down the conclusion to reinforce the answers of the question. As a result, the ability level of ARB student in question number 1 was classified as level of 5 with a very good level of problem-solving ability.

The explanation of students works of number 1 on the test when viewed from the level of students' mathematical problem-solving ability, it obtained that most of the students had mastered the stage of understanding the problem by writing the data that were known and became a problem in the question very well. The stage of planning the problem, the students were also able to write it in the mathematical form and plan a completion strategy even though it was incomplete. Thus, at the stage of implementing the plan, the students were able to carry out the completion based on the plan and got the results. The factor that caused the students to get a fairly good level was that the students were not careful when writing the question into the mathematical sentence forms so that the errors emerged and had long sequences until the students determined the final answer. The evidences of the test results from 20 students that had gotten a number of levels from very good ranges, fairly good were seen from the question number 1, in which all of the students got very good level of range; thus, for the question number 2, there were 16 students and there were 14 students on the number 3 . This was in line with Krismiati (2013) who investigated the implementation of the PMR in groups showed that the learning using problem-solving in groups could improve the students' mathematical problem-solving ability, especially in the aspects of conceptual understanding, processes, strategies, and connections in the problem-solving.

\section{CONCLUSION}

The teacher and students' activities during the learning are carried out well according to the learning stages in the lesson plan $(R P P)$. The teacher guides the students by giving the instructions during the learning process such as: guiding on the work completion of problemsolving, group formation, the students do a discussion and test using the completion stages that have been taught, discussing the discussions question with the group, and presenting the discussion results. The discussion activities are carried out through the activities of students thinking about the problem-solving, the students begin to plan the completion, the students try to solve the problems, find out the results of answers, and present the results of the discussion in front of the class. The final activity of learning is carried out through the activity of reviewing the material that has been studied by giving feedback questions and the students draw the conclusion with the teacher.

It is proven from the results of the test that the students are able to master three stages, namely understanding the problem, planning the completion, and implementing the plan so that it can be categorized as good. The execution of test from numbers 1 to 3 , most of the students 
have mastered the stage of understanding the problem by writing the data that are known and become a problem in the question very well. The stage of planning the problem, the students are also able to write in mathematical form and plan a completion strategy, although sometimes it is incomplete. Thus, at the stage of implementing the plan, the students are able to carry out the completion according to the plan and get the results. The factor that causes the students to get a fairly good level is that the students are not careful when writing the question into the mathematical sentence forms so that the errors emerge and have long sequences until the students determine the final answer. The evidences of the test results from 20 students that had gotten a number of levels from very good ranges, fairly good were seen from the question number 1, in which all of the students got very good level of range; thus, for the question number 2 , there were 16 students and there were 14 students on the number 3 .

\section{REFERENCES}

Anisa, Witri Nur. 2014. Peningkatan Kemampuan Pemecahan Masalah Dan Komunikasi Matematik Melalui Pembelajaran Pendidikan Matematika Realistik Untuk Siswa SMP Negeri Di Kabupaten Garut. Jurnal Pendidikan dan Keguruan Vol. 1 No. 1, 2014, artikel 8. Diakses pada tanggal 7 Maret 2016.

Djamilah B. 2009. Kemampuan Pemecahan Masalah Matematis Mahasiswa Calon Guru Matematika: Apa dan Bagaimana Mengembangkannya. Seminar Nasional Matematika dan Pendidikan Matematika. FMIPA UNY. ISBN: 978-979-16353-3-2. Diakses pada tanggal 21 Maret 2016.

Fauzan, Ahmad. 2003. Rute Belajar dalam RME: Suatu Arah untuk Pembelajaran Matematika. Makalah, disampaikan pada Seminar Nasional Pendidikan Matematika di Universitas Sanata Dharma Yogyakarta 27-28 Maret 2003. Diakses pada tanggal 25 Februari 2016.

Husna, dkk. 2013. Peningkatan Kemampuan Pemecahan Masalah Dan Komunikasi Matematis Siswa Sekolah Menengah Pertama Melalui Model Pembelajaran Kooperatif Tipe ThinkPair-Share (TPS). Jurnal Peluang, Volume 1, Nomor 2, April 2013, ISSN: 2302-5158. FMIPA UPI Bandung. Diakses pada tanggal 21 Maret 2016.

Krismiati, Atik. 2013. Penerapan Pembelajaran Dengan Pendidikan Matematika Realistik (PMR) Secara Berkelompok Untuk Meningkatkan Kemampuan Pemecahan Masalah Matematis Siswa Di Kelas X SMA. Jurnal Ilmiah Program Studi Matematika STKIP Siliwangi Bandung, Vol 2, No.2, September 2013. Diakses pada tanggal 25 Februari 2016.

Lailatul, dkk. 2013. Penerapan ModelPembelajaran Kooperatif Tipe Think Pair Share untuk Meningkatkan Aktivitas Belajar Siswa Pada Pokok Bahasan Matriks. Jurnal Pendidikan Matematika TKI PGRI Sidoarjo Vol 1 No 1, April 3013. ISSN: 2337-8166. Diakses pada tanggal 13 Maret 2016.

Turmudi, Drs, dkk. 2001. Strategi Pembelajaran Matematika Kontemporer. Bandung: JICA UPI.

Wahyuningati, Asih. 2015. Penerapan Model Pembelajaran Kooperatif Tipe Think Pair Share pada Materi Persamaan Garis Lurus kelas VIII SMP Muhammadiyah 2 Malang. Skripsi. Universitas Muhammadiyah Malang.

Wahyuningtyas, Mega. 2014. Implementasi Metode Realistic Mathematics Education Menggunakan Model Open Ended Pada Siswa SMP Kelas VII. Skripsi. Universitas Muhammadiyah Malang.

Yuni, dkk. 2014. Eksperimentasi Model Pembelajaran Two Stay Two Stray (TS-TS) dan ThinkPair-Share (TPS) dengan Pendekatan Matematika Realistik (PMR) Ditinjau Dari 
Aktivitas Belajar Matematika. Jurnal Elektronik Pembelajaran Matematika Vol.2, No.3 hal 250-259, Mei 2014.ISSN: 2339-1685. Universitas Sebelas Maret Surakarta. Diakses pada tanggal 13 Maret 2016. 